\title{
HYDNANGIUM AND RELATED GENERA ${ }^{1}$
}

\author{
CARROLL W. DODGE \\ Mycologist to the Missouri Botanical Garden \\ Professor in the Henry Shaw School of Botany of Washington University
}

AND SANFORD M. ZELLER

Plant Pathologist, Oregon State Agricultural College and Experiment Station Formerly Visiting Fellow, Henry Shaw School of Botany of Washington University

In continuation of our studies on the Hymenogasteraceae (sensu latiore) we present here and in the following paper ${ }^{2}$ the genera belonging to the Hydnangiaceae as defined by Dodge, ${ }^{3}$ except Lycogalopsis of which we have seen too little authentic material to present at this time. Malençon ${ }^{4}$ proposed the family name Asterogasteraceae for essentially this same group, although he notes that Sclerogaster is very aberrant, and apparently he overlooked Maccagnia and Lycogalopsis. $\mathrm{He}$ would also include the gymnocarpous Russulaceae in the same series Astérosporés. Hydnangium has had a relatively simple tradition since its first description, although from time to time discordant elements have been referred to it. The small generic segregates are easily recognized. Since all the genera have not been included here, due to lack of authentic material, we prefer to postpone a discussion of generic relationships until more data are available. The key on the next page will serve to identify material in this and the following paper:

\footnotetext{
1 Published as Technical Paper No. 254, with the approval of the Director of the Oregon Agricultural Experiment Station. Contribution from the Department of Botany in cooperation with the Henry Shaw School of Botany of Washington University.

'Zeller, S. M., and C. W. Dodge. Elasmomyces, Arcangeliella, and Macowanites. Ann. Mo. Bot. Gard. 23: 599-638. 1936.

${ }^{3}$ Gäumann, E. A., and C. W. Dodge. Comparative morphology of fungi. 701 pp. MeGraw Hill Book Co., New York, 1928. (See pp. 485-488.)

- Malençon, G. La série des Astérosporés. Trav. Cryptog. dédiés à Louis Mangin, 377-396. pl. 29. 1931. (See p. 392.)
}

Issued January 8, 1937.

ANn. Mo. Bot. Gard., VoL. 23, 1936 
1. Fructification angiocarpous, but peridium is sometimes absent from a narrow

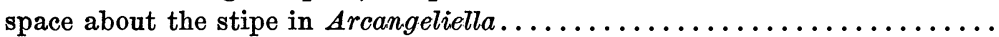

1. Fructification hemiangiocarpous, the lower portion of the gleba completely exposed at maturity .............................. 636)

2. Sterile base present and highly developed at maturity, lignicolous;

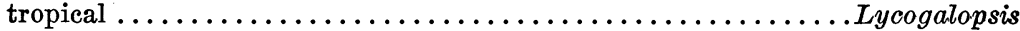

2. Sterile base sometimes present when young but not highly developed and persistent; terrestrial (except Sclerogaster luteocarneus)........... 3

3. Spores very thick-walled, appearing smooth under lower magnifications, but minutely echinulate to verrucose under higher powers............. 4

3. Spores thinner-walled, alveolate to echinulate or rugose........... 5 4. Latex absent, columella usually absent.............Sclerogaster (p. 566) 4. Latex present, columella present........................... 573)

5. Columella absent, spores echinulate to echinate.............. 6

5. Columella present, spores alveolate to echinate................ 7 6. Spores spherical or nearly so, echinulate to echinate....Hydnangium (p. 574)

6. Spores long-ellipsoid, echinate with a broad collar at the base........

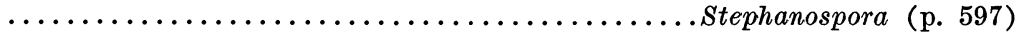

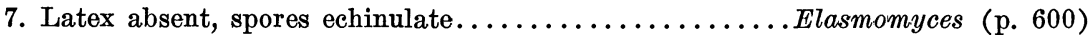

7. Latex present, spores alveolate, rugose, or echinulate.....Arcangeliella (p. 602)

We have used the same color standards, and cited the specimens with the same abbreviations as in our previous work. ${ }^{5}$ Besides those whose aid was gratefully acknowledged in previous papers, we are indebted to Mrs. Olive Rodway for the loan of material from the Rodway Herbarium at the Tasmanian Museum. For financial assistance we are grateful to the American Association for the Advancement of Science (grant in 1923 to the junior author), and to the John Simon Guggenheim Memorial Foundation, which appointed the senior author a fellow to Europe in the autumn of 1930, and to the Science Research Fund of Washington University (grant to the senior author in 1933).

\section{SCLEROGASTER}

Sclerogaster Hesse, Hypog. Deutschl. 1: 84-86. 1891; Sacc. Syll. Fung. 11: 170. 1895; Bataille, Bull. Soc. Myc. France 39: 180. 1923; Coker \& Couch, Gasteromycetes Eastern U. S. \& Canada, 25-26. 1928; E. Fischer, in Engler \& Prantl, Die Nat. Pflanzenfam. ed. 2, 7a: 18. 1933.

The type species of the genus is Sclerogaster lanatus Hesse.

${ }^{5}$ Dodge, C. W., and S. M. Zeller. Hymenogaster and related genera. Ann. Mo. Bot. Gard. 21: 625-708. pl. 18. 1934. (See pp. 625-627.) 
Fructifications small, white, embedded in a thick, flocculent mycelium, attached by rooting fibrils; peridium usually soft; gleba usually pale yellowish, gelified, drying very hard, cavities small, usually filled with spores similar to Leucogaster in shape; basidia small, cylindric to clavate, sterigmata short; spores small, thick-walled, spherical, appearing smooth under lower magnifications but mostly minutely echinate to verrucose under higher powers.

This well-marked genus seems to form a transition between Leucogaster and Hydnangium or Arcangeliella. The spores are much smaller than the average in the above genera and have a relatively thicker wall. In some species there are faint suggestions of a columella but no lactiferous ducts have been seen. In general appearance the fructifications resemble Leucogaster but have very minute cavities. They have usually been included in Hydnangium (Octaviania Auct. non Vitt.) on account of the echinate spores.

The species seem confined to Europe, with one species in southeastern United States, one in tropical America, and one in Oregon and California. Each species seems quite limited in its distribution.

\section{KEY TO SPECIES OF SCLEROGASTER}

1. Peridium separable.............................. 2

1. Peridium not separable.............................. 4

2. Peridium duplex, layers separating readily at maturity; spores 4-6 $\mu$ in

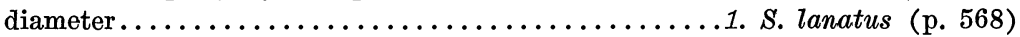

2. Peridium of thin-walled pseudoparenchyma............ S. pacificus (p. 568)

2. Peridium of loosely tangled hyphae in a gel................. 3

3. Peridium $180-250 \mu$ thick..................... S. hysterangioides (p. 569)

3. Peridium about $300 \mu$ thick.................. S. Broomeianus (p. 569)

4. Peridium not more than $100 \mu$ thick.................. 5

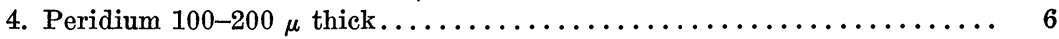

4. Peridium more than $350 \mu$ thick.............. S. luteocarneus (p. 570)

5. Spores $6-8 \mu$ in diameter; peridium of loosely tangled hyphae..........

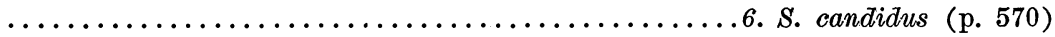

5. Spores 4-5 $\mu$ in diameter; peridium of loose periclinal hyphae.........

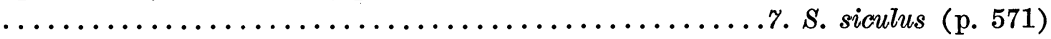

6. Spores 7-9 $\mu$ in diameter, verrucose; peridium $140 \mu$ thick, of periclinal hyphae............................... minor (p. 572)

6. Spores $6-7 \mu$ in diameter, smooth or nearly so; peridium $180 \mu$ thick, of periclinal hyphae........................ S. liospermus (p. 572) 
6. Spores $4-6 \mu$ in diameter, finely echinate; peridium $120-140 \mu$ thick, of loosely tangled hyphae..................... S. compactus (p. 573)

1. Sclerogaster lanatus Hesse, Hypog. Deutschl. 1: 85-86. 1891, excl. syn.

Tllustrations : Hesse, Hypog. Deutschl. 1: pl. 5, f. 11.

Type: in Herb. Bot. Inst. Univ. Marburg, a fragment in Dodge Herb.

Fructifications up to $1 \mathrm{~cm}$. in diameter, spherical, snowwhite, woolly; peridium duplex, inner layer of the same texture as the trama, about $280 \mu$ thick, the outer layer $40 \mu$ thick, of more loosely woven hyphae with abundant crystal deposits tearing away in places; gleba snow-white at first, becoming apricot-yellow, hard; cavities small, not filled with spores; septa about $35 \mu$ thick, of slender periclinal hyphae embedded in a gel; basidia cylindric, $14 \times 4 \mu, 4-8$-spored; sterigmata short; spores spherical, 4-6 $\mu$ in diameter, thick-walled, smooth or nearly so.

Under duff in coniferous woods. England and Germany. May to October.

The type seems still rather immature; at least cavities are still being formed at the inner portion of the "peridium."

Germany: Hessen-Nassau, Cassel, $R$. Hesse, 1887, type (Hesse and Dodge).

England: Kent, Orford, C. E. Broome (Broome Herb. at Kew).

2. Sclerogaster pacificus Zeller \& Dodge, Ann. Mo. Bot. Gard. 22: 370. 1935.

Type: in Zeller and Dodge Herbaria.

Fructifications subspherical, drying $0.8-1.0 \mathrm{~cm}$. in diameter, dirty white; sterile base present; columella not seen; peridium evanescent, about $100 \mu$ thick, pseudoparenchymatous, cells up to $200 \times 30 \mu$, very thin-walled; gleba firm, finally friable, ochraceous-buff; cavities polyhedral, filled with spores; septa of loosely woven, slender hyphae in a gel, thin, 20-30 $\mu$ thick; basidia clavate, soon collapsing and evanescent; spores spherical, with very large verrucae, $9-10$ per great circle, $7-8 \mu$ in diameter.

This species seems aberrant in some respects, with its sterile base and gleba finally becoming friable, but it seems more closely related here than elsewhere. 
Oregon: Coos County, Bandon, S. M. Zeller 7425, type (Zeller and Dodge).

3. Sclerogaster hysterangiomes (Tulasne) Zeller \& Dodge, Ann. Mo. Bot. Gard. 22: 370. 1935.

Hydnangium hysterangioides Tulasne, Fung. Hypog. 76. 1851; DeToni in Sacc. Syll. Fung. 7: 177. 1888.

Octaviania hysterangioides Lloyd, Myc. Notes 67. 1141. 1922.

Illustrations: Tulasne, Fung. Hypog. pl. 21, f. 5 .

Type: in Broome Herb. at British Museum, a slice from type in Lloyd Museum, material from the same locality and collector at the same date, agreeing wholly with the description but determined as Octaviania compacta Tul., in the J. W. Bailey Collection at Brown University.

Fructifications small, $0.6 \times 0.4 \mathrm{~mm}$. when dry, dirty white, surface flocculent, drying slightly rugose; peridium 180-250 $\mu$ thick, composed of loosely tangled hyphae embedded in a gel; gleba maize-yellow to buff-yellow or light brownish-olive in young material; cavities minute, $100 \times 300 \mu$, filled with spores in the older specimens; septa hyaline, easily scissile, 7-10 $\mu$ thick between hymenia, composed of slender, gelified hyphae; basidia clavate, $12 \times 6 \mu$; sterigmata short; spores small, spherical, slightly echinulate, appearing smooth under the lower powers of the microscope, hyaline to dilute cream-color in mass, $4.5-6.5 \mu$ in diameter.

ItALY: Rome, C. E. Broome (under Octaviania compacta Tul., Brown Univ. 56, and Farlow); Rome, Panfilo Gardens, C. E. Broome, 1846, type (Brit. Mus., Kew, and slide from type in Lloyd Mus.).

4. Sclerogaster Broomeianus Zeller \& Dodge, Ann. Mo. Bot. Gard. 22: 370. 1935.

Octaviania compacta Massee, Ann. Bot. 4: 32-33. 1889 [often cited as Monogr. Brit. Gast.].

Illustrations: Massee, Ann. Bot. 4: pl. 1, f. 12.

Type: in Broome Herb. at British Museum and Berkeley Herb. at Kew.

Fructifications $0.5 \times 0.3 \mathrm{~cm}$., depressed-globose, white; peridium separable, $280 \mu$ or more thick, composed of a prosenchyma of hyphae $3-4 \mu$ in diameter; gleba isabella-color or 
dark olive-buff, with minute cavities filled with spores; septa scissile, 20-30 $\mu$ between hymenia, of slender, loosely woven periclinal hyphae embedded in a gel; basidia clavate, 7-8 $\times$ 3-4 $\mu$, with short sterigmata; spores spherical, thick-walled, minutely and sparsely echinate, $5-7 \mu$ in diameter.

Among grass roots. Southern England. October and November.

Exsiccati: Rabenhorst, Fung. Eur. 2502.

England: Gloucestershire, Leigh Wood, C. E. Broome, type (Brit. Mus. and Kew); Kent, Shoreham, C. E. Broome, distributed in Rabenhorst, Fung. Eur. 2502.

5. Sclerogaster luteocarneus (Bresadola) Zeller \& Dodge, Ann. Mo. Bot. Gard. 22: 370. 1935.

Octaviania luteocarnea Bresadola, Ann. Myc. 18: 54. 1920; Trotter in Sacc. Syll. Fung. 23: 601. 1925.

Arcangeliella luteocarnea Lloyd, Myc. Notes 67: 1142. 1922; Rick, Egatea 19: 111. 1934.

Type : in Lloyd Museum.

Fructifications subspherical or obovate, $0.7-1.0 \mathrm{~cm}$. in diameter, smooth, yellowish flesh-color becoming brownish; sterile base conical, about $3 \mathrm{~mm}$. tall, forming the suggestion of a columella; peridium not separable, loose, stupose, 360-380 $\mu$ thick, with outer mycelial patches composed of periclinal hyphae next the gleba and on the outside, with tangled thickwalled hyphae between; gleba yellowish flesh-color; cavities polyhedral; septa white, composed of hyphae 3-4.5 $\mu$ in diameter ; basidia clavate, $22-24 \times 6-7 \mu$; spores spherical, tuberculate-echinulate, $6-7.5 \mu$ in diameter, often with the remains of the sterigma $2-3 \mu$ long.

On wood. Tropical America.

Guadeloupe: Bois de Bains Jaunes, Duss, 1895 (Berlin and Farlow).

BraziL: Rio Grande do Sul, Poco das Antas, J. Rick 51, type (Lloyd Mus. 06025, and Dodge).

6. Sclerogaster candidus (Tulasne) Zeller \& Dodge, Ann. Mo. Bot. Gard. 22: 370. 1935.

Hydnangium candidum Tulasne, Ann. Sci. Nat. Bot. II. 19: 376. 1843 ; Fung. Hypog. 75. 1851; DeToni in Sacc. Syll. Fung. 7: 176. 1888; Lloyd, Myc. Notes 67: 1142. 1922. 
Illustrations: Payer, Bot. Crypt. 114, f. 527; Quélet, Mém. Soc. d'Émulation de Montbéliard 4: $p l$. 4, f. 2 [often cited as Champ. du Jura et des Vosges 2: pl. 4, f. 2]; Roumeguère, Cryptog. Illustr. f. 376; Tulasne, Ann. Sci. Nat. Bot. II. 19: pl. 17, f. 20 ; Fung. Hypog. pl. 21, f. 2.

Type: in Tulasne Herb. at Paris and in Broome Herb. at British Museum.

Fructifications the size of a filbert, globose, regular, somewhat soft, with a minute absorbing base ; fibrils absent; peridium membranaceous, smooth, white, at length becoming light yellow, rimose, not separable, 80-90 $\mu$ thick, of very slender, densely tangled hyphae ; gleba light ochraceous ; cavities small, usually empty; septa thin, $12-15 \mu$ thick, homogeneous, of gelified hyphae, not scissile; basidia 2-3-spored, rarely 4-spored, cylindrical; cystidia narrower, elongate-conical; spores hyaline, more deeply colored with age, becoming fuscous, 6.5-8.5 $\mu$ in diameter, spines short, sometimes appendiculate.

Almost epigeous. Solitary in shady stands of Carpinus. Italy and France.

Italy: Lucea, C. E. Broome (Brit. Mus.).

France: Vienne, Couhe-Verac, Tulasne, Oct. 1841, type (Paris and Brit. Mus.); Doubs, Hérimoncourt, L. Quélet (Upsala); Jura, L. Quélet (Upsala).

7. Sclerogaster siculus Zeller \& Dodge, Ann. Mo. Bot. Gard. 22: 371. 1935.

Sclerogaster lanatus Mattirolo, Malpighia 14: 85-86. 1900. —non Hesse, Hypog. Deutschl. 1: 84. 1891.

Type: in Mattirolo and Dodge Herb. and Lloyd Museum.

Fructifications $0.6 \times 0.4 \mathrm{~cm}$., depressed-globose, white, floccose; peridium duplex, the outer layer variable in thickness, composed of slender, thick-walled hyphae entangling soil particles, inner layer about $90 \mu$ thick, composed of densely woven, periclinal hyphae; gleba ochraceous-tawny, hard; cavities filled with spores; septa about $30 \mu$ thick between hymenia; basidia evanescent; spores brown, thick-walled, sparsely and minutely echinate, $4.1-5.6 \mu$.

Sicily, known only from the type locality.

Sicrux: Fanfani a Cefalu, O. Mattirolo, 4 Apr. 1900, type (Lloyd Mus. and Dodge). 
8. Sclerogaster minor Coker \& Couch, Gast. Eastern U. S. \& Canada, 25-26. 1928.

Illustrations : Coker \& Couch, Gast. Eastern U. S. \& Canada, pl. $17,18,106$.

Type: in Herb. Univ. North Carolina.

Fructifications depressed-globose, $0.3-1.0 \times 0.3-0.7 \mathrm{~cm}$., more or less covered with a cottony mycelium, white ; peridium 300 $450 \mu$ thick, drying $140 \mu$, with a thin, cottony outer layer and a thick, pseudoparenchymatous inner layer, easily separable; gleba white, becoming deep ochraceous-yellow, with suggestions of a columella; cavities minute, filled with spores; septa 60-185 $\mu$ thick, composed of septate hyphae 3-5 $\mu$ in diameter; basidia long, cylindrical, 28-40 × 4-7.4 $\mu, 1-5$-spored; spores 7.4-9.5 $\mu$ in diameter, spherical, smooth at first, becoming warted.

Under Juniperus. North Carolina. August.

North Carolina: Chapel Hill, J. N. Couch 7474, type (Univ. N. Car. Herb.).

9. Sclerogaster liospermus (Tulasne) Soehner, Krypt. Forsch. 1: 393. 1924.

Hydnangium liospermum Tulasne, Fung. Hypog. 76. 1851; DeToni in Sacc. Syll. Fung. 7: 176. 1888; Hesse, Hypog. Deutschl. 1: 84. 1891; Zeller \& Dodge, Ann. Mo. Bot. Gard. 11: 407-408. 1924.

Octaviania liosperma Lloyd, Myc. Notes 67 : 1141. 1923.

Mllustrations : Tulasne, Fung. Hypog. pl. 21, f. 1.

Type: in Tulasne Herb. at Paris.

Fructification size of a pea, firm, spherical, white, with a slight sterile base, here and there enveloped in a white-floccose mycelium, separating in places; peridium about $180 \mu$ thick, not separable, homogeneous, of periclinal hyphae embedded in a gel, continuous with the septa; gleba firm, light ochraceous to apricot-color ; cavities unequal in size, narrow, oblong, radiating from the center to the periphery; septa cartilaginous, gray, variable in thickness, those arising from the base much thicker than the others; spores borne terminally, mostly on short sterigmata, spherical, 6-7 $\mu$ in diameter, smooth or nearly so, rather thick-walled. 
Under fallen leaves in oak woods. France. Autumn.

France: Loiret, Gien, Pare de Beauvoir, Tulasne, type (Paris).

10. Sclerogaster compactus (Tulasne) Saccardo, Syll. Fung. 11: 170. 1895.

Octaviania compacta Tulasne, Giorn. Bot. Ital. $1^{2}$ : 55. 1844; Fung. Hypog. 79. 1851; DeToni in Sacc. Syll. Fung. 7: 160. 1888; Lloyd, Myc. Notes $67: 1142.1922$, in part.

Hydnangium compactum Quélet, Ench. Fung. 247. 1886. —not Harkness, Proc. Cal. Acad. Sci. Bot. III. 1: 250.1899.

Octavianina compacta O. Kuntze, Rev. Gen. Pl. $3^{2}$ : 501. 1898.

Illustrations: Tulasne, Fung. Hypog. pl. 11, f. 3.

Type: in Berkeley Herb. at Kew, Broome Herb. at British Museum, and Tulasne Herb. at Paris.

Fructifications small, spherical, drying about $6 \mathrm{~mm}$. in diameter, covered by a loose, flocculent mycelium; columella penetrating to the center of the fructification or a little beyond; peridium 120-140 $\mu$ thick, not separable, of large, loosely tangled, thin-walled hyphae; gleba cinnamon-buff, texture very hard as in Leucogaster; cavities filled with spores; septa thin, about $15 \mu$ thick between hymenia, composed of more or less periclinal, thick-walled hyphae embedded in a gel ; basidia evanescent; spores spherical, sparsely and minutely warted, thickwalled, 4-6 $\mu$ in diameter.

France: Var, Hyères, Tulasne, 1844, 1845, type (Kew, Brit. Mus., and Paris); Provence, E. Boudier, 1900 (Paris).

\section{MACCAGNIA}

Maccagnia Mattirolo, R. Accad. Naz. dei Lincei. V. 13 ${ }^{12}$ : 1317. 1922 ; E. Fischer in Engler \& Prantl, Die Nat. Pflanzenfam. ed. 2, 7a: 23. 1933.

The type species of the genus is Maccagnia carnica Mattirolo.

Fructifications small, spherical, drying hard and horny; columella highly developed; lactiferous ducts abundant; cavities filled with small hyaline, thick-walled spores on zig-zag hyphae, as in Leucogaster and Leucophlebs, which soon form a gel in 
which the basidia and spores are later borne; spores spherical with a thick epispore, rather small, echinate.

This genus seems intermediate between Sclerogaster, Leucogaster, and Arcangeliella, having the spores and texture of a Sclerogaster, the general ontogeny of a Leucogaster, and the columella and lactiferous ducts of an Arcangeliella. It will be remembered that Sclerogaster compactus and S. luteocarneus have a more or less well-developed columella but in all other characters seem closer to Sclerogaster than to Maccagnia. So far this genus is known from a single collection from Italy.

MaCcagnia Carnica Mattirolo, R. Accad. Naz. dei Lincei. V. 13 ${ }^{12}$ : 13-17. 1922.

Illustrations: R. Accad. Naz. dei Lincei. V. 13'12: pl. 1.

Type: Probably in Mattirolo Herb., a portion in Patouillard Herb. at Farlow Herb.

Fructifications small, $0.8-1.0 \mathrm{~cm}$. in diameter, spherical, sometimes attenuate at the base, becoming horn-like when dry, isabelline-yellow to isabelline-umber; peridium 120-150 $\mu$ (mean $125 \mu$ ) thick, composed of very slender periclinal hyphae with very abundant, varicose, tortuous, moniliform, lactiferous ducts filled with a transparent yellow substance; columella branched, forming the veins; gleba chestnut-color; cavities radially arranged, somewhat circular, at first filled with small, hyaline, thick-walled spores $3-4 \mu$ in diameter borne on zig-zag hyphae; septa thin, of highly gelified hyphae with lactiferous ducts; basidia clavate on a long pedicel, gelifying early, 4-, rarely 2-spored, sterigmata filiform; spores spherical, slightly appendiculate, epispore relatively thick, yellow-greenish, 4-5 $\mu$, occasionally $6 \mu$, in diameter.

ItaLy: Udine, Gemona, Maccagni (Mattirolo Herb. and Farlow).

\section{HYDNANGIUM}

Hydnangium Wallroth in Dietrich, Fl. Reg. Boruss. [Fl. Königr. Preuss.] 7: no. 465. 1839; Corda, Anleit. z. Stud. Myc. 114, lxxxiii. 1842 ; Icon. Fung. 5: 28. 1842 ; Tulasne, Ann. Sci. Nat. Bot. II. 19: 376. 1843; Fung. Hypog. 74. 1851; Rabenhorst, Deutschl. Krypt.-Fl. 1: 249. 1844; Fries, Summa Veg. 
Scand. 436. 1849; Berkeley, Outlines Brit. Fungol. 293. 1860; Winter in Rabenhorst, Krypt.-Fl. Deutschl. ed. 2. 1: 877. 1883; Quélet, Ench. Fung. 247-248. 1886; DeToni in Sacc. Syll. Fung. 7: 175-177. 1888; Hesse, Hypog. Deutschl. 1: 81-84. 1891; E. Fischer in Engler \& Prantl, Die Nat. Pflanzenfam. I. 1**: 310. 1899; and ed. 2, 7a: 30-31. 1933; Hollós, Magyar. Földalatti Gombai, 96-97, 207-208. 1911.

Martellia Mattirolo, Malpighia 14: 78-82. 1900; Saccardo \& Sydow in Sacc. Syll. Fung. 16: 252. 1902.

Octaviania Auct. (pro parte) especially Lloyd, Myc. Notes 7: 1138-1142. 1922 (for discussion of nomenclature see Ann. Mo. Bot. Gard. 23: 603-604. 1936).

The type species of the genus is Hydnangium carneum Wallroth. The type species of Martellia is M. mistiformis Mattirolo. The type species of Octaviania, as used by authors subsequent to Tulasne including Lloyd, is $O$. asterosperma Vitt.

Fructifications spherical to slightly irregular, without sterile base or columella; peridium filamentous or prosenchymatous, rarely pseudoparenchymatous, more or less uniform in texture, without lactiferous ducts; gleba often fragile as in $\mathrm{Hy}$ menogaster, usually light-colored; basidia mostly 4- or 2spored, usually projecting beyond the general level of the hymenium at maturity; spores spherical or nearly so, echinate, often with long slender spines not alveolate, or with ridges as is frequently the case in Arcangeliella.

Various characters have been used to separate this genus from the genus Arcangeliella. The early authors emphasized the presence or absence of sterile base, referring here species without one, and to Octaviania those with a well-developed one. While this character may be of some theoretical importance from the standpoint of developmental morphology it is very difficult to apply, as in very few species does the sterile base persist to full maturity, with a result that immature specimens were apt to be referred to Octaviania and very mature ones to Hydnangium. In the present treatment this practice has been followed, but it has not been used as a key character, as other characters are easier to apply. In the latter part of the last century, ease of dehiscence of the peridium was used. 
Again this character is difficult to apply, as so many variations occur and too often the peridium is partly lacking rather as an accident to the individual specimens than because of any morphological character. In general, the species with a separable peridium are referable to Arcangeliella and those with a more persistent peridium remain in Hydnangium. An important exception is $H$. mistiforme Matt. which was segregated by Mattirolo chiefly on this character as Martellia. The spores are also brown rather than hyaline. Neither character seems sufficiently important to us to warrant generic segregation in the light of our present knowledge of the group. Lloyd, Myc. Notes 7: 1139-1142. 1922, redefined Arcangeliella as having a gleba "hard cartilaginous (horny when dry), hard to cut" including the type species $A$. Borziana Cav. and A. luteocarnea (Bres.) Lloyd, the latter species here treated as Sclerogaster although slightly aberrant in that genus. All the other echinulate and alveolate species were referred to Octaviania. Hardness of the gleba seems to us an accidental character, dependent partly on the thickness of septa, their state of gelification, and method or care in drying.

\section{KEY TO SPECIES OF HYDNANGIUM}

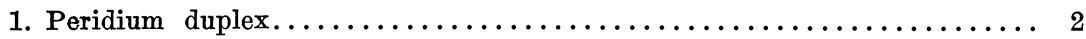

1. Peridium simplex, without pseudoparenchyma............... 5

2. Pseudoparenchyma present in one layer of peridium........... 3

2. Pseudoparenchyma absent; spores dark brown.............. 4

3. Spores dark brown....................... H. citrinum (p. 577)

3. Spores hyaline........................ Honticola (p. 578)

4. Spores $6-8 \mu$ in diameter; peridium $800 \mu$ thick....... 3. H. Eisenii (p. 578)

4. Spores $10-13 \mu$ in diameter; peridium thinner.........4. H. laeve (p. 579)

5. Spores hyaline or nearly so $\ldots \ldots \ldots \ldots \ldots \ldots \ldots \ldots \ldots \ldots \ldots \ldots \ldots \ldots$

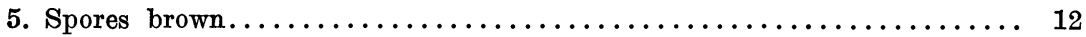

6. Spores $5-6 \mu$ in diameter.................. H. compactum (p. 580)

6. Spores 7.4-9 $\mu$ in diameter..................6. H. Parksii (p. 580)

6. Spores mostly over $20 \mu$ in diameter, echinulate, spines 3-3.5 $\mu$ long

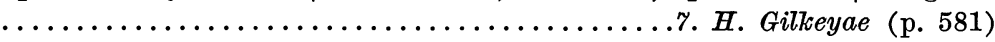

6. Spores $10-20 \mu$ in diameter........................ 7

7. Peridium white, $400 \mu$ thick.................. H. album (p. 581)

7. Peridium pinkish or reddish........................ 8

7. Peridium yellow or brownish....................... 9

8. Peridium $30-40 \mu$ thick....................... H. pila (p. 582)

8. Peridium 110-120 $\mu$ thick...... 10a. H. carneum var. purpureum (p. 584)

8. Peridium 150-270 $\mu$ thick................. Ho. carneum (p. 582) 
9. Sterile base prominent, hemispheric, stipe short, slender; peridium $200 \mu$

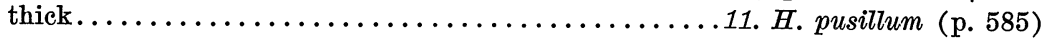

9. Sterile base not prominent....................... 10

10. Peridium thick, $1200-1300 \mu \ldots \ldots \ldots \ldots \ldots \ldots$. 12. H. luteolum (p. 585)

10. Peridium $150-280 \mu$ thick........................... 11

10. Peridium 110-120 $\mu$ thick......10a. H. carneum var. purpureum (p. 584)

10. Peridium $60-80 \mu$ thick. ................. Archeri (p. 586)

10. Peridium thin, septa thick..............

11. Spores 15-16 $\mu$ in diameter................ Honosporum (p. 587)

11. Spores $8.5-12 \times 11-14 \mu \ldots \ldots \ldots \ldots \ldots \ldots \ldots \ldots 16$. H. aurantium (p. 588)

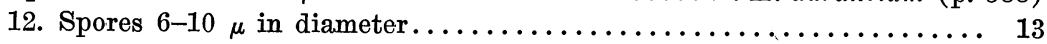

12. Spores $10-20 \mu$ in diameter............................. 14

13. Peridium separable, white-olivaceous............1\%. H. mistiforme (p. 588)

13. Peridium not separable, capucine-yellow or pink.....18. H. Thaxteri (p. 589)

14. Peridium white, changing to deep vinaceous, drying vinaceous, 500-600 $\mu$ thick............................. purpureum (p. 589)

14. Peridium white, changing to dark brown on exposure, about $300 \mu$ thick

14. Peridium white, unchanging, $600-700 \mu$ thick . 20. H. Hessei (p. 590) $\ldots \ldots \ldots \ldots \ldots \ldots \ldots \ldots \ldots \ldots \ldots \ldots \ldots \ldots \ldots \ldots \ldots \ldots$. H. lanigerum (p. 591)

14. Peridium pale flesh-color, $140 \mu$ thick..........22. H. javanicum (p. 592)

14. Peridium brownish........................... 15

14. Peridium black, $260-270 \mu$ thick............23. H. nigricans (p. 592)

15. Peridium thick, $900-1000 \mu \ldots \ldots \ldots \ldots \ldots \ldots \ldots$.24. H. tuberculatum (p. 593)

15. Peridium 400-500 $\mu$ thick; Australia.............25. H. densum (p. 593)

15. Peridium 300-400 $\mu$ thick, auburn or chestnut........26. H. luteum (p. 594)

15. Peridium 50-60 $\mu$ thick, dark brown to black.......2\%. H. Soehneri (p. 595)

15. Peridium 40-50 $\mu$ thick, waxy yellow drying tawny...28. H. cereum (p. 595)

1. Hydnangium citrinum (Harkness) Zeller \& Dodge, Ann. Mo. Bot. Gard. 22: 371.1935.

Octaviania citrina Harkness, Proc. Cal. Acad. Sci. Bot. III. 1: 252. 1899; Saccardo \& Sydow in Sacc. Syll. Fung. 16: 248249. 1902.

Type: cotype in Dudley Herb. at Leland Stanford Jr. Univ.

Fructifications depressed-globose to irregular, $1.3 \times 2 \mathrm{~cm}$, white becoming ochraceous-tawny in alcohol, dirt clinging to the peridium in spots; peridium duplex, $200 \mu$ thick, the outer portion of strands of parallel hyphae which grow outward and entangle dirt, with pseudoparenchyma of large cells within; gleba orange, becoming ochraceous-tawny in alcohol; cavities empty; septa 70-80 $\mu$ thick, composed of pseudoparenchyma with cells 10-11 $\mu$ in diameter; basidia clavate, 4-spored, $20 \times$ $11 \mu$; sterigmata 6-7 $\mu$ long with slightly swollen bases; spores 
spherical, echinulate, pedicellate, yellow-brown, 10-12 $\mu$ in diameter.

Under Arctostaphylos glaucus. California. April.

The cotypes in the Dudley Herbarium have no data associated with them other than the numbers on the bottles and the names which Harkness gave them. Harkness mentions three localities in his original description and there are three bottles labeled Octaviania citrina in the Dudley Herb. Two of them belong clearly to this species, while the third, of very different structure although of much the same color, seems to be discolored specimens of H. carneum. Harkness cites as his localities: Oat Hill Quicksilver Mine, Solano County ; Camp Taylor, Marin County ; and Calistoga, Napa County.

California: H. W. Harkness 155b, 15\%, cotype (Stanford).

2. Hydnangium monticola (Harkness) Zeller \& Dodge, Ann. Mo. Bot. Gard. 22: 372.1935.

Octaviania monticola Harkness, Proc. Cal. Acad. Sci. Bot. III. 1: 254. 1899. Saccardo \& Sydow in Sacc. Syll. Fung. 16: 248. 1902.

Illustrations: Harkness, Proc. Cal. Acad. Sci. Bot. III. 1: $p l$. $42, f .3$.

Type: cotype in Dudley Herb. at Leland Stanford Jr. Univ.

Fructifications irregular, $2 \times 3 \times 3 \mathrm{~cm}$., flexible, buff, becoming Verona brown in alcohol; sterile base prominent, no columella; peridium duplex, $300 \mu$ thick, the outer layer up to $100 \mu$ thick, composed of thin-walled, slender, hyaline hyphae, the inner layer pseudoparenchymatous; gleba a little lighter than the peridium, spongy; cavities empty; septa hyaline, 80-120 $\mu$ thick, of rather indefinite structure resembling the outer peridium; basidia clavate, $35 \times 6-7 \mu$, 4-spored; sterigmata short; spores $10-12 \mu$ in diameter, minutely verrucose.

Mountain regions in sandy soil. California. April.

CallFornia: Placer County, Auburn, H. W. Harkness 13, cotype (Stanford); Santa Clara County, Alma, H. E. Parks 404 (Univ. Cal. and Zeller).

3. Hydnangium Eisenit (Harkness) Zeller \& Dodge, Ann. Mo. Bot. Gard. 22: 371. 1935. 
Melanogaster Eisenii Harkness, Proc. Cal. Acad. Sci. Bot. III. 1: 259. 1899.

Type: cotype in Dudley Herb. at Leland Stanford Jr. Univ.

Fructifications $1.5 \mathrm{~cm}$. in diameter, brown becoming russet to clay-color in alcohol; peridium about 500-600 $\mu$ thick, composed of very slender, thin-walled, compactly woven hyphae, with clamp connections, frequently ending in pyriform bodies, but composing a single, hyaline, homogeneous layer, with a dark brown surface of the same texture, about $7 \mu$ thick; gleba dark brown; cavities densely crowded with spores; septa brownish, soon disappearing, composed of small, gelified, interwoven hyphae; basidia inconspicuous, $25 \times 7 \mu$; sterigmata long; spores brown, globose, echinate, $6-8 \mu$ in diameter.

Lower California. January.

Mexico: Baja California, Cabo S. Lucas, G. Eisen, cotype (Harkness 116, Stanford, and histological slide of a fragment in Zeller).

4. Hydnangium laeve (Hesse) Zeller \& Dodge, Ann. Mo. Bot. Gard. 22: 372. 1935.

Octaviania laevis Hesse, Hypog. Deutschl. 1: 80-81. 1891.

Octavianina laevis O. Kuntze, Rev. Gen. Pl. 32: 501. 1898.

Octaviania levis Saccardo, Syll. Fung. 11: 169. 1895.

Arcangeliella laevis (Hesse) Dodge, Ann. Mo. Bot. Gard. 22: 368. 1935.

Illustrations: Hesse, Hypog. Deutschl. 1: pl. 7, f. 15-17.

Type: location unknown to us but authentic material in Herb. Bot. Inst. Univ. Marburg.

Fructifications spherical, $1.5 \mathrm{~cm}$. in diameter, smooth, white then russet to almost black in alcohol; peridium thin, duplex, outer layer sloughing off leaving patches composed of septate hyphae, inner layer $30-40 \mu$ thick, stupose, brownish-yellow, composed of closely woven, gelified hyphae, becoming smaller next the gleba; gleba white becoming yellowish and finally Sudan brown in alcohol, cavities small and long, soon filled with spores ; septa very thin, later yellowish, composed of compactly woven, gelified hyphae $2 \mu$ in diameter; basidia clavate, short, paraphyses shorter; sterigmata as long as the diameter of the mature spore or longer; spores colorless, becoming yellowishbrown, 10-13 $\mu$ in diameter, with large blunt spines. 
Under birch. Hessen-Nassau, Germany, and Oregon. July to September, mostly in August.

The specimen studied was collected in the type locality twelve years later than the original specimen but three years before the species was described and was determined by Hesse.

Germany: Hessen-Nassau, Altmorschen, R. Hesse, VII/88; Aue, R. Hesse, V/89 (both Hesse and Dodge).

OREgoN: Marion County, Salem, S. M. Zeller 2186 (Zeller).

5. Hydnangium compactum Harkness, Proc. Cal. Acad. Sci. Bot. III. 1: 250. 1899; Saccardo \& Sydow in Sace. Syll. Fung. 16: 255. 1902.—not Quélet, Ench. Fung. 247. 1886.

Type: cotype in Dudley Herb. at Leland Stanford Jr. Univ.

Fructification depressed-globose, $2 \mathrm{~cm}$. in diameter, white becoming Sayal brown to tawny-olive in alcohol; peridium 120$130 \mu$ thick, composed of hyaline, slender, compactly woven, gelified hyphae; gleba light ochraceous-buff, cavities empty; septa $80 \mu$ thick, composed of hyaline, slender, compactly woven gelified hyphae; basidia oblong, $20 \times 4-5 \mu$, sterigmata short; spores very sparsely echinulate, with very small spines, $5-6 \mu$ in diameter.

Under Ceanothus. California and Australia. May to June.

California: Placer County, Auburn, H. W. Harkness 191, type (Stanford); Santa Clara County, H. E. Parks 1060 (Univ. Cal., Dodge, and Zeller); Guadaloupe, H. E. Partes 153, 422, 801 (Univ. Cal., Dodge, and Zeller); Alma, H. E. Parks 162a (Univ. Cal., Dodge, and Zeller 1638).

Australia: S. Australia, J. B. Cleland 2 (Cleland and Dodge).

6. Hydnangium Parksii Zeller \& Dodge, sp. nov.

Fructificationes magnae, $2-3 \mathrm{~cm}$. diametro metientes, sphericae, albidae, fulvae conservatae, superficie glabra, basis sterilis columellaque non visae; peridium ad $640 \mu$ crassitudine, hyphis subpericlinalibus dense contextum; gleba alba, "ochraceous buff" conservata, locellis parvis; septa $65-70 \mu$ crassitudine, hyphis dense contexta; basidia cylindrica, bispora, $22 \times$ 6-7 $\mu$; sporae 7.4-9 $\mu$, hyalinae, minute echinulatae.

Type : in Univ. Cal. Herb.

Fructifications large, $2-3 \mathrm{~cm}$. in diameter, spherical, white becoming tawny in alcohol, surface smooth, no sterile base nor columella present; peridium up to $640 \mu$ thick, composed of 
densely woven, more or less periclinal hyphae; gleba white becoming ochraceous-buff in alcohol; cavities small; septa about 65-70 $\mu$ thick, of compactly woven, thin-walled hyphae; basidia cylindric, 2-spored, $22 \times 6-7 \mu$; spores $7.4-9 \mu$ in diameter, minutely echinulate, hyaline.

It is possible that this is still immature, in which case the thickness of the peridium and of the septa as given above is probably too great and the spore markings too minute.

CALIFornia: Santa Clara County, Guadaloupe, H. E. Parks 521 (Univ. Cal.).

7. Hydnangium Gilkeyae Zeller \& Dodge, Ann. Mo. Bot. Gard. 22: 371. 1935.

Type: in Oregon State Agr. Coll., Dodge, and Zeller Herbaria.

Fructifications oblong to subspherical, about $4.5 \times 3 \times 3 \mathrm{~cm}$, brittle; surface glabrous with innate reticulate veins, buff with brownish stains, drying pinkish-buff to tawny-olive, with the veins slightly darker; no sterile base showing in youngest specimens seen ( $1 \mathrm{~cm}$. broad) ; peridium 150-200 $\mu$ thick, drying $70-85 \mu$, of hyaline prosenchyma, appearing finely stupose when dried; gleba white to slightly creamy when fresh, drying pale orange-yellow to maize-yellow; cavities medium size; septa cream-color, hyaline sub lente, of loosely interwoven, large hyphae, scissile at angles, $35-40 \mu$ thick; basidia 1-2-spored, clavate, protruding beyond the paraphyses; spores large, subspherical, mostly longer than broad, yellowish-brown, with large echinulae about 3-3.5 $\mu$ long, pedicellate, 18-22 × 14.5$8.5 \mu$ including the spines, epispore $0.7-1.0 \mu$ thick.

Hypogeous, under Corylus californicus. Oregon. May.

Oregor: Linn County, near the Peoria Road, Helen M. Gilkey, type (Oregon State, Dodge, and Zeller 2334).

8. Hydnangium album Harkness, Proc. Cal. Acad. Sci. Bot. III. 1: 251. 1899; Saccardo \& Sydow in Sacc. Syll. Fung. 16: 255. 1902.

Type: cotype in Dudley Herb. at Leland Stanford Jr. Univ.

Fructifications spherical, $1 \mathrm{~cm}$. in diameter, dirty white becoming brownish in alcohol; peridium simplex, $400 \mu$ thick, composed of hyaline, slender, closely woven, branched hyphae; 
gleba ochraceous; cavities minute, empty; septa $75 \mu$ thick, composed of hyaline, slender, closely woven, branched hyphae; basidia clavate, $20 \times 6 \mu$, sterigmata $6-7 \mu$ long; spores dilute yellowish, minutely reticulate with short sharp spines, 11-15 $\mu$ in diameter.

In the forest. California. Spring.

In the outer part of the peridium and in the tramal tissues are dark brown bodies resembling latex organs, but the species has not been referred to Arcangeliella since no columella was reported in the type.

California: Napa County, Calistoga, H. W. Harkness 178, cotype (Stanford).

9. Hydnangium pila Patouillard, Bull. Soc. Myc. France 26: 201. 1910; Saccardo \& Trotter in Sacc. Syll. Fung. 21: 495. 1912.

Illustrations: Patouillard, Bull. Soc. Myc. France 26: 202, f. 2. 1910.

Type: Patouillard Herb. at Farlow Herb.

Fructifications depressed-globose to irregular, $2-3 \mathrm{~cm}$. in diameter, white, reddening in air ; peridium continuous above, often lacunose below, puberulent due to hyaline, cylindric cells of hyphae, 30-40 $\mu$ thick, dense and tenacious near the gleba, easily separable, mycelium white, fibrous, little developed; gleba firm, white, then reddish; no sterile base; septa composed of slender, cylindric filaments supporting a pseudoparenchymatous subhymenial layer; basidia obtuse and rounded at the summit, rapidly attenuated below into a cylindric portion, 30$35 \times 15-20 \mu, 4$-spored, sterigmata short, pointed; spores colorless, later very pale tawny, spherical to slightly ellipsoid, 10 $12 \mu$ in diameter or 10-14 $\times 9-11 \mu$, echinulate, with a large oil drop.

Semi-hypogeous in oak woods. Central Europe. August.

Germany: Bayern, Ehrharting, E. Soehner (Soehner and Dodge).

France: Jura, Lepinay, N. Patouillard, type (Farlow).

10. Hydnangium carneum Wallroth in Dietrich, Fl. Reg. Boruss. [Fl. Königr. Preuss.] 7: no. 465. 1839; Tulasne, Fung. Hypog. 75. 1851; Winter in Rabenhorst, Kryptog.-Fl. Deutschl. ed. 2. 1: 877. 1883; DeToni in Sacc. Syll. Fung. 7: 175-176. 
1888; Massee, Ann. Bot. 4: 37. 1889 [often cited as Monogr. Brit. Gast.] ; Hesse, Hypog. Deutschl. 1: 82-83. 1891; Boudier, Icones Myc. 4: 98. 1905-1910; Th. M. Fries, Svensk Bot. Tidsskr. 3: 273-274. 1909; Hollós, Magyar. Földalatti Gombai, 97. 207-208. 1911; Th. C. E. Fries, Ark. f. Bot. 179': 12. 1922; Bataille, Bull. Soc. Myc. France 39: 192. 1923; ? E. Fischer, Geobot. Inst. Rübel in Zürich, Veröffentl. 3: 576-578. 1925.

Octaviania carnea Corda, Icones Fung. 6: 36. 1854; Lloyd, Myc. Notes 67: 1139-1140. 1922, in part.

QOctaviana carnea Rodway, Papers \& Proc. Roy. Soc. Tasmania 1923: 157. 1924; ?Verwoerd, S. Afr. Jour. Sci. 22: 164. 1925.

Octaviania? mollis De Notaris, Comment. Soc. Crittog. Ital. 1: 33. 1861; DeToni in Sacc. Syll. Fung. 7: 160. 1888.

Octavianina mollis O. Kuntze, Rev. Gen. Pl. 3²: 501. 1898.

Mllustrations: Boudier, Icones Myc. 1: pl. 192; Bucholtz, Материалы къ морфологіи и систематикеъ подземныхъ грибовъ . . . Издан. Естеств. Ист. Музея Графоини Е. П. Шереметевой въ с. Михайловскомъ Московской Губ. 1: pl. 4, f. 27-28; Corda, Anleit. z. Stud. Myc. pl. D, f. 47: 11-13; Icones Fung. 6: pl. r, f. 66; DeBary, Vergl. Morphol. d. Pilze, ed. 2, 67, f. 28; P. Hennings, Verh. Bot. Ver. Prov. Brandenburg 40: pl. 1, f. 18; Hesse, Hypog. Deutschl. 1: pl. 2, f. 18-19; pl. 5, f. 16 ; Istvanffi, Ber. Deutsch. Bot. Ges. 13: pl. 37, f. 49; Massee, Ann. Bot. 4: pl. 1, f. 14; Nees von Esenbeck, Th. \& A. Henry, Syst. d. Pilze 1: pl. 27, f. 1-6; Petri, Rendic. Cong. Bot. Palermo, 148-149; Nuovo Giorn. Bot. Ital. N. S. 9: pl. 14; Roumeguère, Cryptog. Illustr. f. 374b; Ruhland, Bot. Zeit. 59: pl. 7, f. 25-30; Tulasne, Fung. Hypog. pl. 21, f. 3 ; Van Bambeke, Mem. Acad. Roy. Belg. 54: $p l .1-3$.

Type: Bot. Mus. Berlin, Kew, and Paris. The type distribution of Octaviania mollis De Notaris in Erb. Critt. Ital. 1052.

Fructifications spherical or oblately spheroidal, pale fleshcolor, smooth; no columella nor sterile base seen; peridium 150-270 $\mu$ thick, compact, fibrous, stupose; gleba very pale, drying brownish, brittle, cavities irregular, medium size; septa 20-28 $\mu$ thick between hymenial layers, about $55 \mu$ to tops of paraphyses, stupose, composed of slender gelified hyphae; 
basidia 2-spored, projecting above hymenium, 18-20 × 10-13 $\mu$; sterigmata 5-6 $\mu$ long; cystidia large, smooth, hyaline; spores spherical, echinulate (echinulae plus exospore about $3 \mu$ ), averaging 16 echinulae on median limb of circle, dilute honeycolored en masse, hyaline singly, 9.5-14 $\mu$ in diameter (averaging about $16 \mu$ including echinulae).

Europe and America. October.

There is a trace of a sterile base in Rabenhorst, Fung. Eur. 675.

Exsiccatr: Erb. Critt. Ital. 1052, under Octaviania mollis; Rabenhorst, Fung. Eur. 675; Herb. Viv. Myc. 1318; Sydow, Mycoth. Marehica, 3726; de Thümen, Mycoth. Univ. 109.

Finland: Helsingfors, Bot. Gard., W. Nylander (Paris).

SwEDEN : Upsala, Th. M. Fries \& R. Fries, in Rabenhorst, Fung. Eur. 675 (copy in Farlow); Bot. Trädgard, Th. M. Fries, 1866 (Upsala).

Germany: Schlesien, L. Becker, in de Thümen, Mycoth. Univ. 109 (Lloyd Mus. and Mo. Bot. Gard.) ; Brandenburg, Grünewald, F. Klotzsch, type (Berlin, Kew, and Paris) ; Berlin, P. Hennings, in Sydow, Mycoth. Marchica, 3726 (copies in Farlow, Lloyd Mus. 0234, and another specimen with same date, Lloyd Mus. 4149, and Dodge, also as v. caldariorum, Berlin); Klotzsch (Kew); Bayern, Wolfratshaus, E. Soehner 7\%4 (Soehner, Berlin, and Dodge).

AUsTria: Niederösterreich, Schneeberggebiet, F. von Hoehnel (von Hoehnel Herb. B2603 at Farlow).

ITALY: Trentino, G. Bresadola, Nov. 1894 (Upsala); Genova, F. Baglietto, in Erb. Critt. Ital. 1052, under the name Octaviania mollis De-Notaris, type? (copies in Farlow and Lloyd Mus.); Roma, O. Mattirolo (Lloyd Mus.).

France: Alpes Maritimes, Antibes, Poirault (Farlow, Lloyd Mus. 6039, and Dodge) ; Golfe Jouan, L. Rolland, Feb. 1900 (Paris).

HollaND: Amsterdam, Oudemans 307 (Upsala).

Scotland: Glasgow Botanical Garden, Dickson, Oct. 1873 (Berkeley Herb. at Kew) ; Edinburgh (M. C. Cooke Herb. at Kew).

Portugal: Lisbon, C. Torrend, Dec. 1907 (Paris as f. minor).

MASSACHUSETTS: Cambridge, H. von Schrenk (Mo. Bot. Gard. 1607); H. Webster (Farlow).

Oregon: Benton County, Corvallis, S. M. Zeller 2566 ; Linn County, Peoria, S. $M$. Zeller 2588 (both Zeller).

CALIFornis: Alameda County, Berkeley, R. A. Harper, 3 collections (N. Y. Bot. Gard.) ; Dale Parks \& H. E. Parks 390 (Univ. Cal., Dodge, and Zeller); Santia Clara County, Saratoga, H. E. Parks 496 (Univ. Cal.); Alma, H. E. Parks Z10, 152 (Univ. Cal., Dodge, and Zeller); Guadaloupe Mines, H. E. Parks 435 (Univ. Cal., Dodge, and Zeller).

JAMAICA : Cinchona, W. A. \& Edna L. Murrill 498 (N. Y. Bot. Gard. and Dodge). UruguaY: Montevideo, Miguelete, G. Herter 85821 (Dodge).

10a. var. Purpureum Petch, Ann. Roy. Bot. Gard. Peradeniya 7: 78. 1919. 
Type: At Peradeniya and Kew Herbaria.

Fructification $1.0 \times 0.7 \mathrm{~cm}$., reniform, drying wrinkled, fawncolor to Natal brown; peridium 110-120 $\mu$ thick, stupose, composed of gelified strands of dark brown hyphae as in $H$. Archeri; gleba tawny-olive to isabella-color, cavities large, empty; septa $20 \mu$ thick between hymenia, of slender, compact hyphae; basidia soon collapsing and evanescent, sterigmata long; spores hyaline or nearly so, spherical, 10-11 $\mu$ in diameter, with slender, short spines about 24 per great circle.

Known only from the type locality.

The position of this variety is uncertain. In peridial characters it seems closer to $H$. Archeri, while its spores are suggestive of $H$. carnea or some species of Arcangeliella.

Cerlon: Hakgala, T. Petch 5480 type, 6438 (Peradeniya, Kew, and Dodge).

11. Hydnangium Pusiludm Harkness in Zeller \& Dodge, Ann. Mo. Bot. Gard. 22: 372. 1935.

Type: in Dudley Herb. at Leland Stanford Jr. Univ.

Fructifications $1 \mathrm{~cm}$. in diameter, cinnamon-brown; sterile base prominent, ending in a hemispherical knob at top and prolonged below into a short, slender stipe; peridium about $200 \mu$ thick, composed of thin-walled, hyaline, parallel hyphae; gleba buckthorn-brown; cavities large, irregular, empty; septa $100 \mu$ thick, composed of thin-walled, slender, hyaline hyphae, beginning to gelify; basidia broadly clavate, with two sterigmata 3-4 $\mu$ long; spores spherical, $15 \mu$ in diameter, with prominent, long, slender spines.

CALIFORNIA: H. W. Harkness 282, type (Stanford).

12. Hydnangium luteolum Harkness, Proc. Cal. Acad. Sci. Bot. III. 1: 251. 1899; Saccardo \& Sydow in Sacc. Syll. Fung. 16: 255. 1902.

Type: cotype in Dudley Herb. at Leland Stanford Jr. Univ.

Fructifications small, irregular, white turning brown; peridium 1200-1300 $\mu$ thick, composed of thin-walled, very slender, closely woven hyphae; gleba orange-yellow; cavities small, empty; septa 35-40 $\mu$ thick, composed of coarse, gelified hyphae; basidia pyriform, 35-40 × $8 \mu$, sterigmata short; spores 
spherical, $12 \mu$ in diameter, with small short spines not very closely placed, pedicellate.

In somewhat sandy soil beneath Libocedrus decurrens. California. July.

CaLIFornia: Placer County, Alta, H. W. Harkness 100, cotype (Stanford).

13. Hydnangium Archeri (Berkeley) Zeller \& Dodge, Ann. Mo. Bot. Gard. 22: 371. 1935.

Octaviania Archeri Berkeley in J. D. Hooker, Bot. Antarctic Voy. III. Fl. Tasmaniae 2: 263-265. 1859; DeToni in Sacc. Syll. Fung. 7: 160. 1888; Cooke, Handbook Austral. Fungi, 246. 1892; Rodway, Papers \& Proc. Roy. Soc. Tasmania 1911: 25. 1912.

Octavianina Archeri O. Kuntze, Rev. Gen. Pl. 3²: 501. 1898. Type: in Kew Herb.

Fructifications obovate, drying 7-8 mm. in diameter, chocolate to burnt umber, sterile base large (fide Berkeley); peridium highly gelified, thin, 60-80 $\mu$ thick, composed of interwoven strands of coarse, parallel hyphae; gleba deep olive-buff to dark olive-buff, hard, cartilaginous; cavities large, polygonal, empty; septa chocolate, cartilaginous, 30-40 $\mu$ thick, composed of slender, gelified, parallel, brown hyphae; basidia not evident on account of the collapse of the hymenium; spores spherical, with long slender equal spines 24 per great circle, 2-3 $\mu$ long, spores without spines 12-14 $\mu$ in diameter.

On sandy ground. Tasmania, Australia, and New Zealand.

Both Oregon specimens are too young for certain determination.

Tasmania: Archer, type (Kew); Hobart, L. Rodway 118 (Kew), 087, 1108 (Lloyd Mus. and Dodge).

South Australia: Morialta, J. B. Cleland 11 (Cleland and Dodge) ; Mt. Lofty, J. B. Cleland 12 (Cleland and Dodge).

New Zealand: Colenso 1480 (Kew); Invercargill, J. B. Cleland 9 (Cleland and Dodge).

?OREgon: Benton County, Corvallis, S. M. Zeller 7254 (Zeller); H. P. Barss (Zeller 8183).

14. Hydnangium aurantiacum Heim \& Malençon, Treb. Mus. Cienc. Nat. Barcelona 15 [Ser. Bot. 3] : 69-74. 1934.

Hydnangium carotaecolor Codina \& Font-Quer, Cavanill. 3: 169-170. 1931. 
Tllustrations: Heim \& Malençon, Treb. Mus. Cienc. Nat. Barcelona 15 [Ser. Bot. 3]: 70, f. 16.

Type: not seen by us, probably in Paris or Barcelona.

Fructifications $1.5-2 \mathrm{~cm}$. in diameter, subspherical, wrinkled, rough, from yellow to orange (jaune orangé, $\mathrm{K}$, Code 136, 141); peridium thin, arachnoid, absent in places, composed of yellow (Code 161) fibres; no columella or sterile base, although the base is provided with a tuft of rooting whitish or yellow fibrils, mycelium yellow; gleba dense, bright yellow (orange safrané, Code 131), cavities small, crowded; septa comparatively thick; basidia clavate, cylindric or obconic, 38-40 × 8-10 $\mu$, with 2-4 sterigmata 3.5-4 $\times 1.2-1.6 \mu$; spores spherical or somewhat obovate, 11-16 $\mu$ in diameter, with two walls and a thick epispore composed of terete, obtuse tubercles $1.5 \mu$ long arranged singly or in rows or joined by an imperfect reticulum, pale yellow, often with remains of the sterigma $3-4(-6) \mu$ long, $2 \mu$ in diameter.

In wooded moist ravine facing north, under Quercus Ilex. Montserrat. October.

15. Hydnangium monosporum Boudier \& Patouillard, Jour. de Bot. [Morot] 2: 445. 1888; Patouillard, Tab. Anal. Fung. 7: 71. 1889; Saccardo, Syll. Fung. 9: 280-281. 1891; Boudier, Icones Myc. 4: 98-99. 1905-1910.

Octaviania monospora Lloyd, Myc. Notes 67 : 1141. 1922.

Illustrations: Boudier, Icones Myc. 1: pl. 193; Patouillard, Tab. Anal. Fung. f. 692.

Type: cotype in Lloyd Museum.

Fructifications ovate-pyriform, irregularly depressed above, 3-4 cm. in diameter, ochraceous-tawny, somewhat papillate, squamulose at the surface; peridium 150-220 $\mu$ thick, composed of parallel, hyaline hyphae ; gleba firm, white, becoming yellowish and tawny where wounded; cavities small, empty ; septa 30$50 \mu$ thick, composed of loosely interwoven, hyaline hyphae 3$5 \mu$ in diameter; basidia oblong-clavate, 30-40 $\times 12 \mu$, with a single long sterigma tapering above; spores brownish, spherical, minutely echinulate, appearing smooth under low power, appendiculate, uniguttulate, $15-16 \mu$ in diameter ; odor of pineapples. 
In clay soil. Germany and southern France.

Germavy: Bayern, München, E. Soehner 1060 (Soehner and Dodge).

France: Nice, J. Barla, cotype (ex Boudier Herb. in Lloyd Mus. 5343, Dodge, Patouillard Herb. at Farlow, and Upsala, com. Bresadola sub H. candidum).

16. Hydnangium aurantium (Harkness) Zeller \& Dodge, Ann. Mo. Bot. Gard. 5: 30. 1918.

Rhizopogon aurantius Harkness, Proc. Cal. Acad. Sci. Bot. III. 1: 257. 1899 ; Saccardo, Syll. Fung. 16: 251. 1902.

Type: cotype in Dudley Herb. at Leland Stanford Jr. Univ.

Fructifications subspherical, solitary, 1-2 cm. in diameter, dirty white drying yellowish tawny to Mars brown, dark brown in alcohol ; peridium 160-280 $\mu$ thick, homogeneous, of fine interwoven hyphae which become gelified at maturity, hyaline, with outer layer about 50-60 $\mu$ thick, of very compact, more or less erect, fine hyphae becoming brown; gleba orange when fresh, drying warm buff to ochraceous-buff or pale orangeyellow, cavities subglobose to irregular, empty; septa 30-60 $\mu$ thick, composed of slender hyphae, compactly interwoven, becoming scissile; basidia clavate, hyaline, 2-spored, 20-35 × 8$10 \mu$, sterigmata 5-7 $\mu$ long; paraphyses cylindrical, septate; cystidia capitate with narrow necks, 48-52 $\times 11-14 \mu$; spores subglobose to obovoid, pediculate, $8.5-12 \times 11-14 \mu$, dilute olivaceous, finely echinulate-alveolate, exospore about 1-1.5 $\mu$ thick; odor pleasant as of certain polypores.

Hypogeous, in open coniferous woods. Western Washington, Oregon, and California. May to October.

This species is hunted by pine squirrels and other rodents.

Washington: Jefferson County, Quiniault, C. A. Brown \& C. H. Kauffman (Univ. Mich. and Zeller).

Oregon: Benton County, 7 miles west of Alsea, S. M. Zeller 1960 (Zeller); Coos County, Sunset Beach, near Cape Arago Lighthouse, N. L. Gardner 408 (Univ. Calif., Dodge, and Zeller).

CaLIFoRnia: Marin County, Mt. Tamalpais, H. W. Harkness 74, cotype (Stanford) ; Santa Clara County, Saratoga, H. E. Parks 1142 \& C. W. Dodge 1152 [immature] (Dodge).

17. Hydnangium mistiforme (Mattirolo) Zeller \& Dodge, Ann. Mo. Bot. Gard. 22: 372. 1935.

Martellia mistiformis Mattirolo, Malpighia 14: 78-82. 1900; Saccardo \& Sydow in Sacc. Syll. Fung. 16: 252. 1902. 
Illustrations: Mattirolo, Malpighia 14; pl. 1, f. 1-4.

Type: probably in Mattirolo Herb., a portion in Patouillard Herb. at Farlow. Herb.

Fructifications spherical and irregular, about $1 \mathrm{~cm}$. in diameter, olivaceous-white; peridium smooth, easily separable, variable in thickness, composed of gelified compact hyphae, the outer ones enclosing grains of sand; gleba rather firm, umber to chestnut; cavities small, irregular, gyrose with a tendency to arise from the sterile base; septa cottony-filamentous, scissile; basidia short-cylindric, 35-40 $\mu$ long, arising from subhymenial pseudoparenchyma, 4-spored; sterigmata slender, 4-5 $\mu$ long; spores spherical or slightly ellipsoidal, about $10 \mu$ in diameter, umber, slightly echinate.

ITALY: Sardinia, Orune, U. Martelli, type (Patouillard Herb. at Farlow).

18. Hydnangium Thaxteri Zeller \& Dodge, Ann. Mo. Bot. Gard. 22: 372. 1935.

Type: in Farlow Herb. at Harvard Univ.

Fructifications spherical, color of crushed strawberries, drying capucine-yellow; columella scarcely more than thickened septum branching and disappearing in the middle of the fructification; peridium 125-130 $\mu$ thick, outer layer $30 \mu$ thick, of closely woven, slender hyphae, and inner layer $100 \mu$ thick, of larger, more loosely woven, periclinal hyphae; gleba orangebuff to light ochraceous-buff ; cavities minute ; septa 50-60 $\mu$, of slender interwoven hyphae, subhymenium pseudoparenchymatous; basidia short-cylindric; sterigmata long; spores 7-8 $\mu$ in diameter, spherical, about 20-24 slender spines per great circle.

This species was found growing with Rhizopogon occidentalis under leaves on a dry hilltop above Concepción. Thaxter states "Color dirty cream running to crushed strawberry red.' Since we have not seen $R$. occidentalis with more than pale pink tints, we have assumed that the deeper color mentioned applied to our species.

ChILE: Concepción, R. Thaxter, Nov. 1905, type (Farlow).

19. Hydnangium purpureum (Coker \& Couch) Zeller \& Dodge, comb. nov. 
Octaviania purpurea Coker \& Couch, Gast. Eastern U. S. \& Canada, 50. 1928.

Illustrations : Coker \& Couch, Gast. Eastern U. S. \& Canada, pl. $30,31,111$.

Type: in Univ. North Carolina Herb., a portion in Dodge Herb.

Fructifications $0.6-2.5 \mathrm{~cm}$. in diameter, drying 0.4-1.6 cm., oblately spheroidal to irregularly lobed, with branched rhizomorphs, white turning vinaceous to deep vinaceous on exposure or wounding, drying vinaceous, without sterile base or columella; peridium 1-2 mm. thick, drying 150-450 $\mu$ thick, separable, composed of slender, densely woven hyphae 3-4 $\mu$ in diameter, and a few much larger, thick-walled hyphae 11$16 \mu$, often ending in large spherical cells; gleba white at first becoming olive-brown to deep blackish-brown; septa white, 30$40 \mu$ thick, of slender gelified hyphae with groups of cavities separated by much thicker septa; basidia 20-25 × 7.4-11.2 $\mu$ when young, sending up an epibasidum 4.4-5.5 $\mu$ in diameter, bearing a single spore so that the mature basidium is flaskshaped, 30-44 × 5.5-7.8 $\mu$ and early collapsing; spores broadly ellipsoidal, 9.5-12.5 $\mu$ in diameter, thick-walled, with large warts.

North Carolina. July and August.

The systematic position of this species is not clear, and it is with hesitation that we have referred it to Hydnangium. We have seen no trace of sterile base and columella. The large thick-walled hyphae of the peridium are very suggestive of lactiferous ducts, but the contents do not stain more deeply with eosin as do the contents of latex hyphae in Arcangeliella. The basidium with the differentiation of epibasidium is unusual in the present state of our knowledge, although suggestions of this kind of development are present in some of the Bornean species of Arcangeliella.

North Carolina: Chapel Hill, Battle's Branch, J. N. Couch, type (Univ. N. Car. 7468, and Dodge).

20. Hydnangium Hessei (O. Kuntze) Zeller \& Dodge, Ann. Mo. Bot. Gard. 22: 371. 1935.

Octavianina Hessei O. Kuntze, Rev. Gen. Pl. 3²: 501. 1898. 
Octaviania Hesseana Saccardo \& Sydow in Sacc. Syll. Fung. 14: 267. 1899.

Octaviania mutabilis Hesse, Hypog. Deutschl. 1: 77-78. 1891; Sacc. Syll. Fung. 11: 169. 1895-not Octaviania mutabilis Roumeguère, Rev. Myc. 7: 23. 1885.

Type: location not certainly known to us, but material so determined by Hesse collected in July, 1891, is in the Bot. Inst. Univ. Marburg.

Fructifications $1 \mathrm{~cm}$. in diameter, white then yellowishwhite, and finally dark brown flecked with yellowish-white, becoming greenish in light as in $A$. asterosperma, later dark brown or violet; peridium about $200 \mu$ thick, easily separable in both fresh and dry material, fibrous to woolly, composed of hyaline, parallel hyphae of variable thickness next the gleba, hyphae thicker, more loosely woven and brown, thin-walled next the outside; gleba snow-white at first becoming dark brown, fragile at first becoming cartilaginous; cavities long, irregular and filled with spores; septa composed of loosely woven, septate hyphae and slender subhymenial hyphae; basidia short, clavate, paraphyses shorter than the basidia, sterigmata filiform; spores very dark brown, 12-13 $\mu$ in diameter, coarsely echinate.

Germany. July and September.

Germany: Hessen-Nassau, R. Hesse, July 1891 (Hesse); Bayern, München, E. Soehner 961 (Soehner and Dodge).

21. Hydnangium lanigerum (Hesse) Zeller \& Dodge, Ann. Mo. Bot. Gard. 22: 372. 1935.

Octaviania lanigera Hesse, Hypog. Deutschl. 1: 79-80. 1891; Sacc. Syll. Fung. 11: 169. 1895.

Octavianina lanigera O. Kuntze, Rev. Gen. Pl. 3²: 501. 1898. Illustrations: Hesse, Hypog. Deutschl. 1: pl. 6, f. $7-8$.

Type: location unknown to us, but authentic material in Farlow Herb. at Harvard Univ.

Fructifications $2.5 \times 2 \times 2 \mathrm{~cm}$, reniform, pure white; fibrils snow-white, small, scanty; peridium 600-700 $\mu$ thick, loose, stupose to almost byssoid, composed of large, hyaline, septate hyphae $8-9.5 \mu$ in diameter, sterile base broadly pulvinate; 
gleba tawny to russet; septa 100-150 $\mu$ thick, composed of loosely woven, septate, branched hyphae $10 \mu$ in diameter; basidia cylindric, 2-3-spored; spores spherical, 12-14 $\mu$ in diameter, tawny, with broad echinulae (10-14 per great circle) 2-3 $\mu$ long, walls 1-1.5 $\mu$ thick.

Under Betula. Germany. Early autumn.

Germany: Hessen-Nassau, Altmorschen, $R$. Hesse (Farlow).

22. Hydnangium Javanicum P. Hennings, Beiblatt zur Hedwigia 40: (27). 1901; Saccardo \& Sydow in Sacc. Syll. Fung. 16: 255. 1902 ; von Höhnel, K. Akad. Wiss. Wien, math.naturw. Kl. Sitzungsber. Abt. I. 117: 1017. 1908.

Type: in Bot. Mus. Berlin.

Fructifications subspherical, 1.8-2.1×1.4-1.7 cm., drying 0.7$1.0 \mathrm{~cm}$. in diameter, pale flesh-color, surface smooth or slightly tomentose; peridium about $140 \mu$ thick, separable, of large, loosely woven hyphae $4 \mu$ in diameter embedded in a gel; gleba flesh-color becoming brown, elastic, cavities minute, sinuous; septa about $40 \mu$ thick, composed of slender, compactly woven, gelified hyphae; basidia clavate, 20-30 × 5-8 $\mu, 4$ sterigmata; spores spherical, densely echinate, brownish-olivaceous, 15$18 \mu$ in diameter, with the spines yellowish, $3-4 \times 0.5-0.7 \mu$; weak odor of rancid almonds.

JAVA: Tjibodas, M. Fleischer, 11 Oct. 1900, type (Berlin).

23. Hydnangium nigricans Kalchbrenner, Grevillea 10: 107. 1882 ; Saccardo, Syll. Fung. 11: 172. 1895.

Type: in Kew Herb. and in Bot. Mus. Berlin.

Fructifications $1.5 \times 2 \mathrm{~cm}$., depressed-globose, drying black, smooth, no trace of sterile base or columella in sliced fructification; peridium 260-270 $\mu$ thick, composed of large, thinwalled prosenchyma; gleba ochraceous-tawny, cavities small; septa thin, 14-15 $\mu$ between hymenia (in dried material), appearing as slender, irregular, gelified hyphae but perhaps similar to the peridium, badly collapsed; basidia about $30 \times 11 \mu$, collapsing in the upper half on the separation of the spore; spores $12-19 \mu$ in diameter, dark brown, with closely set, conical spines on a thick epispore.

Under Acacia in grassy fields. South Africa. 
One should note that Kalchbrenner also cites Macowan 1211 as Macowanites agaricinus.

SoUTH AFrICA: Somerset East, near Mt. Boschberg, P. Macowan 1211, type (Kew and Berlin).

24. Hydnangium tuberculatum (Hesse) Zeller \& Dodge, Ann. Mo. Bot. Gard. 22: 373. 1935.

Octaviania tuberculata Hesse, Hypog. Deutschl. 1: 75-77. 1891; Sacc. Syll. Fung. 11: 169. 1895.

Octavianina tuberculata O. Kuntze, Rev. Gen. Pl. $3^{2}$ : 501. 1898.

Illustrations: Hesse, Hypog. Deutschl. 1: pl. $7, f .14 ; p l .9$, f. 16-24.

Type: location unknown to us. Specimen examined from type locality collected two years after the type, determined by the author before the original description was published, but not cited.

Fructifications $1.3 \times 2 \mathrm{~cm}$., depressed-globose, very irregular, deeply and thickly furrowed on the upper surface, white at first then yellowish, and finally brown vinaceous-buff to avellaneous in alcohol; sterile base disappearing at maturity; peridium 900-1000 $\mu$ thick, not separable, fibrous, composed of thinwalled, undulating, loosely woven, brownish hyphae 6-7 $\mu$ in diameter, becoming white next the gleba, woolly in the deep furrows; gleba mummy-brown, cavities very irregular, partially filled with spores; septa thin toward the outside, 90-100 $\mu$ thick, thicker between the cavities in the center of the fructifications, composed of large, thin-walled, septate hyphae 4-5 $\mu$ in diameter (almost pseudoparenchyma), white finally becoming light brown ; basidia clavate with 3-4 sterigmata, filiform, half the length of the spores, paraphyses shorter, slenderer, and septate; spores with spiny, thick exospore, dark brown, 12$13 \mu$ in diameter; odorless.

Under Fagus sylvatica. Hessen-Nassau, Germany. September and October.

Germany: Hessen-Nassau, Michelbach, R. Hesse, $\mathrm{X} / 88$ (Hesse).

25. Hydnangium densum Rodway, Papers \& Proc. Roy. Soc. Tasmania 1919: 112. 1920; 1923: 160. 1924; Trotter in Sacc. Syll. Fung. 24: 1328. 1928. 
Hydnangium Mouchettii herb. nom.

Type: in Rodway Herb. at Tasmanian Museum. Type of H. Mouchettii in Herb. Dept. Agr., Pathologist's Branch, Victoria.

Fructifications depressed-globose, 1-1.5 cm. in diameter when dry, pale ochre when fresh becoming cinnamon-buff to tawny-olive; peridium about $450 \mu$ thick when dry, stupose, composed of thick-walled, brown hyphae 4-5 $\mu$ in diameter; gleba mummy-brown where cut, gray where fractured, resembling a Melanogaster, cavities filled with spores, polyhedral; septa very variable in thickness, composed of loosely woven, gelified, hyaline hyphae $2 \mu$ in diameter, more compact in the subhymenium ; basidia not seen ; spores very dark brown, spherical, densely echinate, $10-11 \mu$ in diameter.

The systematic position of this species is wholly obscure. Basidia if present are evanescent. From its spore-filled cavities it might be placed in Melanogaster or Chondrogaster, although its spore shape is closer to the dark-spored species of Arcangeliella. It is even possible that it belongs in the Sclerodermataceae near Pompholyx.

Austradia: South Australia, Aldgate, [Mouchette?] (sub Hydnangium Mouchettii in Herb. Dept. Agr., Pathologist's Branch No. after 1444).

TASMania: Mt. Nelson Range, L. Rodway, type (Rodway).

26. Hydnangium luteum (Hesse) Zeller \& Dodge, Ann. Mo. Bot. Gard. 22: 372. 1935.

Octaviania lutea Hesse, Jahrb. f. wiss. Bot. 16: 255. 1885 ; Hypog. Deutschl. 1: 74-75. 1891; DeToni in Sacc. Syll. Fung. 7: 491. 1888; Hollós, Magyar. Földalatti Gombai, 96, 207. 1911.

Illustrations : Hesse, Jahrb. f. wiss. Bot. 16: pl. 6, f. 7-9; Hypog. Deutschl. 1: pl. 6,f.5-6; pl.7,f. 49.

Type: in Upsala and Farlow Herbaria.

Fructifications up to $2.5-3 \mathrm{~cm}$. in diameter, irregular to subglobose, becoming auburn, chestnut, or Mars brown in alcohol, surface smooth, fibrillose-villous, with lighter, almost white patches due to thicker portions of the peridium ; peridium 300$400 \mu$ thick in the thicker portions, 150-200 $\mu$ in the thinner, loosely stupose, composed of large, thin-walled, hyaline hyphae 
as in Rhizopogon maculatus, fascicles of erect hyphae on the surface giving the villous appearance; sterile base not seen in older specimens, but evident in the younger; gleba cheesy in consistency, cinnamon to tawny-olive, cavities small, irregular, filled with spores ; septa 40-50 $\mu$ thick, stupose, composed of parallel hyphae 3-4 $\mu$ in diameter; basidia 2-4-spored, clavate, $24-28 \times 12-13 \mu$; spores 12-13 $\mu$ (15-16 $\mu$ with echinulae), tawny, with 12-18 spines on the periphery of an optical section of the spore.

Under birches. Germany. Summer.

Germany: Hessen-Nassau, Altmorschen, $R$. Hesse, type (Upsala and Farlow).

27. Hydnangium Soenneri Zeller \& Dodge, Ann. Mo. Bot. Gard. 22: 372. 1935.

Type: in Soehner, Zeller, and Dodge Herbaria.

Fructifications spherical to reniform, drying $0.6 \times 0.9 \mathrm{~cm}$., very dark brown to black, no sterile base or columella seen; peridium 50-60 $\mu$ thick, of small-celled, gelified prosenchyma; gleba Sudan brown, cavities relatively large, empty; septa thin, somewhat scissile, of large, thick-walled, brownish, loosely woven hyphae; basidia large, cylindrical, soon collapsing; spores ellipsoidal, 15.4-18.2 ×12.4-14 $\mu$, dark brown.

Germany: Bayern, Wolfratshausen, Pupplinger Heide, E. Soehner, type (Soehner, Zeller, and Dodge).

28. Hydnangium cereum Soehner, Kryptog. Forsch. 1: 394. 1924.

Type: in Soehner Herb. and portion in Dodge Herb.

Fructifications $2-3 \mathrm{~cm}$. in diameter, spherical, smooth, glabrous, very firm, white then wax-yellow, often becoming tawny or Van Dyck brown in old age, drying tawny, base slightly rugose or depressed, no rhizomorphs; peridium thin, up to $100 \mu$ thick; gleba white, later slightly yellowish, browning on exposure to air, tawny at maturity, drying ochraceous-buff, cavities small but conspicuous; spores spherical, hyaline at first, becoming slightly tawny, 10-15 $\mu$, mostly $12.5 \mu$, in diameter, exospore slightly spinose when young, becoming coarsely echinate; odor slight when fresh, when dry, like that of apples. 
In loam in oak forest. Ehrharting near Mühldorf. Very rare.

Germany: Bayern, Ehrharting bei Mühldorf am Inn, E. Soehner 527, type (Soehner and Dodge).

\section{EXCLUDED SPECIES}

1. Leucophlebs Clelandi (Rodway) Zeller \& Dodge, comb. nov.

Hydnangium Clelandi Rodway, Papers \& Proc. Roy. Soc. Tasmania 1924: 159. 1925.

Type: in Rodway Herb. at Tasmanian Museum.

Fructifications irregularly spherical, 1-2 cm. in diameter, whitish-ochre, drying light yellowish-olive to olive-yellow; peridium thin, membranous, white, continuous with the trama, outer $110 \mu$ of large hyphae 7-8 $\mu$ in diameter, with gelified walls, inner $150 \mu$ of slender, thin-walled hyphae $2-3 \mu$ in diameter, densely interwoven; gleba dull brown-clay to umber, becoming browner with age, drying snuff-brown to bister, cavities about $1 \mathrm{~mm}$., not contorted but densely crowded with spores ; septa 14-15 $\mu$ thick, of densely woven, slender hyphae; spores pale yellow, globose, smooth, becoming obscurely verrucose, $20-22 \mu$ in diameter, very thick-walled, somewhat suggesting L. magnata Harkn.

The type, consisting of a single fructification, does not seem to be in condition to show how the spores are borne, as all trace of hymenium has disappeared. In spore characters and general texture of the fructification it seems much closer to Leucophlebs than to Hydnangium.

TASmania: Hobart, Cascade Valley, L. Rodway, type (Rodway).

2. Hydnangium microsporium Rodway, Papers \& Proc. Roy. Soc. Tasmania 1919: 111. 1920; 1923: 160. 1924; Trotter in Sacc. Syll. Fung. 24: 1328. 1928.-not Octaviania microsporium Mattirolo, nom. herb. in Lloyd Mus.

Type: in Rodway Herb. at Tasmanian Museum.

After a study of the type, we agree with Cunningham that this species should be referred to Lycoperdon Gunnii Berkeley. 


\section{STEPHANOSPORA}

Stephanospora Patouillard, Bull. Soc. Myc. France 30: 349. 1914.

The type species of the genus is Hydnangium caroticolor Berkeley.

Fructifications spherical or nearly so, without sterile base or columella; peridium thin and fragile; gleba fragile; basidia cylindrical; spores long-ellipsoidal, coarsely echinate, with a broad collar at the base surrounding the sterigma.

It is with some hesitation that we have recognized this genus which is very close to Hydnangium in most characters, but its spore is so distinct and we have seen nothing which suggests a transition between it and Hydnangium. At present only a single species from England and central Europe is known.

Stephanospora caroticolor (Berkeley) Patouillard, Bull. Soc. Myc. France 30: 349. 1914.

Hydnangium caroticolor Berkeley, Ann. \& Mag. Nat. Hist. I. 13: 351-352. 1844; Ibid. I. 18: 76. 1846; Outlines British Fungol. 293. 1860; Tulasne, Fung. Hypog. 75. 1851; Winter in Rabenhorst, Krypt.-Fl. Deutschl. ed. 2. 1: 877-878. 1883; DeToni in Sacc. Syll. Fung. 7: 176-177. 1888; Massee, Ann. Bot. 4: 36-37. 1889 [often cited as Monogr. Brit. Gast.]; Hesse, Hypog. Deutschl. 1: 83-84. 1891; Patouillard, Bull. Soc. Myc. France 26: 203-204. 1910.

Octaviania caroticolor Corda, Icones Fung. 6: 36. 1854; Lloyd, Myc. Notes 67 : 1141. 1922.

Illustrations: Berkeley, Outlines British Fungol. pl. 20,f. 1; Cooke, Handbook Brit. Fung. 1: 357 ; Corda, Icones Fung. 6: pl. 7, f. 65; Massee, Ann. Bot. 4: pl. 1, f. 6; Patouillard, Bull. Soc. Myc. France 25: 203, f. 3; Tulasne, Fung. Hypog. pl. 21, f. 4; Winter in Rabenhorst, Kryptog.-Fl. Deutschl. ed. 2. 1: 871.

Type: in Berkeley Herb. at Kew, and Broome Herb. at British Museum.

Fructifications oblong, about $2 \mathrm{~cm}$. in diameter, slightly tomentose, pale orange-red [exactly like that of a fine carrot, Berkeley \& Broome] when fresh, drying amber-brown to Argus 
brown; peridium thin, fragile; gleba beautiful orange-red [Berkeley \& Broome] when fresh, drying raw sienna, cavities small, empty; septa 10-14 $\mu$ thick, composed of parallel hyphae; basidia short-cylindric, sterigmata $3-4 \mu$ long; spores longellipsoidal, with a smooth hyaline fold at the base, coarsely echinate, 8-13 $\times 6-7 \mu$.

Central and western Europe.

Germany: Bayern, Kaufbeuren, E. Soehner 239 (Dodge, Zeller, and Berlin); Hessen-Nassau, Aue, R. Hesse, Aug. 1891 (Hesse).

France: Jura, Lepinay, N. Patouillard, Août, Oct. 1912 (Patouillard at Farlow). Switzerland: Bassecourt, P. Konrad (Lloyd Mus. 046); Zurich, G. Winter 1809 (Stanford and Berlin).

England: C. E. Broome (Lloyd Mus. 0231.); Gloucestershire, near Clifton, $C$. $E$. Broome, type (Kew, Brit. Mus.) ; Leigh Wood, near Bristol, C. E. Broome 310 (ex Herb. J. W. Bailey in Brown Univ., Curtis Herb. at Farlow, and 4 collections Brit. Mus.); Dorsetshire, Swanage, Ballard Down, C. E. Broome (2 collections Brit. Mus., and Berlin). 